\title{
IMPLEMENTATION OF CERTAINTY FACTOR IN AN EXPERT SYSTEM FOR DIAGNOSING ORAL CANCER
}

\author{
Nurhasan Nugroho ${ }^{1 *}$, Nurdiana Handayani ${ }^{2}$, Rachmat Destriana ${ }^{3}$, Tia Ernawati ${ }^{4}$ \\ 1Program Studi Pendidikan Teknologi Informasi \\ Universitas Bina Bangsa \\ https://binabangsa.ac.id/ \\ nurhasan.nugroho@binabangsa.ac.id \\ 2,3Program Studi Teknik Informatika \\ Universitas Muhammadiyah Tangerang \\ https://umt.ac.id/ \\ nurdiana.handayani@ft-umt.ac.id,rachmat.destriana@ft-umt.ac.id \\ ${ }^{4}$ Program Studi Komputerisasi Akuntansi \\ AMIK Citra Buana Indonesia \\ https://cbi.ac.id/ \\ tia.bkdserdos@gmail.com
}

\begin{abstract}
Abstrak
Kanker mulut atau kanker rongga mulut adalah kanker yang menyerang jaringan epitel mukosa rongga mulut. Kanker merupakan penyakit dengan angka kematian yang tinggi. Oleh karena itu, sangat penting untuk dapat memberikan bantuan pengetahuan kepada masyarakat yang masih cukup rendah pengetahuannya tentang kanker khususnya kanker mulut. Salah satu cara untuk membantu mendiagnosis penyakit adalah dengan menggunakan sistem pakar. Pada penelitian ini dikembangkan aplikasi sistem pakar untuk mendiagnosis kanker mulut berdasarkan gejala dan menghasilkan solusi diagnosis dan pengobatan. Sistem pakar yang dikembangkan menggunakan algoritma certainty factor (CF). Di mana mampu mengatasi ketidakpastian dengan memberikan nilai tingkat kepercayaan dari para ahli dan pengguna. Dari hasil pengujian akurasi menunjukkan nilai sebesar 87\%, sehingga sistem dapat berfungsi dengan baik.
\end{abstract}

Kata kunci: certainty factor, sistem pakar, kanker mulut

\begin{abstract}
Oral cancer or oral cavity cancer is cancer that attacks the epithelial tissue of the oral mucosa. Cancer is a disease with a high mortality rate. So, it is very important to be able to provide information to the public about oral cancer. One way to help diagnose disease is to use an expert system. In this study, an expert system application was developed to diagnose oral cancer based on symptoms and produce a diagnosis and treatment solution. The expert system developed using the certainty factor algorithm (CF). Where is able to overcome uncertainty by providing a value level of trust from experts and users. From the results of the accuracy test, it shows a value of $87 \%$, so the system can function properly.
\end{abstract}

Keywords: certainty factor, expert system, oral cancer

\section{INTRODUCTION}

One of the important functions for the human body in maintaining its life is the function of metabolism. Metabolic function is obtained from energy through the digestive process. Providing information and knowledge about the digestive system is important, this is because the digestive system plays a very important role in producing nutritious food that can support the performance of human activities (Napianto, Rahmanto, Borman, Lestari, \& Nugroho, 2018). This process involves several organs in the human body, one of which is the mouth or oral cavity. Abnormalities or problems that occur in the mouth will be fatal, including the lack of nutrients that enter the body. One of the dangerous diseases that can attack the mouth is oral cancer or oral cavity cancer (Napianto et al., 2018). Oral cancer or also known as oral cavity cancer is a cancer that attacks the mucosal 
epithelial tissue in the oral cavity (including the lips, gums, floor of the mouth, tongue, cheeks and palate). Cancer is a disease with a high mortality rate. WHO noted, in 2018 there were 18.1 million new cases of cancer with a mortality rate of 9.8 million (Irmawati, 2020). The number of cancer patients in Indonesia is quite large, but the number of cancer specialists in Indonesia is still very minimal (Nikita, Sadawarti, \& Kaur, 2020). Moreover, public knowledge about cancer, especially oral cancer is still low. Therefore, it is very important to be able to provide knowledge assistance to Indonesian people who still lack knowledge about cancer. For that we need a system that can provide knowledge and diagnose oral cancer.

Today the field of Artificial intelligence has penetrated in everyday life and is used to facilitate human activities. Artificial intelligence examines how to build systems that have the ability to complete work like humans in solving problems (Borman, Napianto, Nurlandari, \& Abidin, 2020). Expert system is one part of the field of artificial intelligence. An expert system is a computer system that adopts the knowledge of people who are experts in certain fields in solving problems that are usually solved by experts (Fahmi et al., 2020). In an expert system, knowledge, facts, and ways of thinking are needed to solve problems that are usually solved by an expert. However, an expert usually gets uncertain answers and statements from patients, such as: probably, most likely, or almost certainly (Agustina, Pratomo, Wibawa, \& Rahayu, 2017). To build an expert system with uncertain input statements, it is possible to use the certainty factor (CF) approach. CF is an algorithm that can explain the level of certainty of size based on facts so that it can provide an overview of the level of confidence (Desnelita et al., 2018). CF has the advantage that it can provide calculation results based on the level of confidence of the symptoms experienced by the user, so that it can produce answers to cases of uncertainty that produce better truth (Fahmi et al., 2020). CF can be applied in expert systems to build rule-based applications, to generate analysis of information about a particular problem and to generate mathematical analysis in solving problems. CF can be applied to assist in the identification and diagnosis of disease.

Several previous studies have shown that $\mathrm{CF}$ is able to provide good results and accuracy. The first research, regarding the development of an expert system for diagnosing dental and oral diseases using the CF method (Pasaribu, Sihombing, \& Suherman, 2020). This research produces an expert system that has an accuracy rate of $99 \%$, which is obtained from a comparison of diagnoses between the results of an expert and an expert system. The research is about the application of the CF method to diagnose rheumatic diseases (Hairani, Abdillah, \& Innuddin, 2019). In this study, CF was able to produce an accuracy of $80 \%$, which means the expert system built has good performance. In addition, this study explains that CF can overcome uncertainty or incomplete information provided by users. Furthermore, research on the digestive tract disease system in expert children uses the CF method (Astuti, Sutarno, \& Rasim, 2017). Testing is done by comparing the results of system diagnostics with expert diagnoses. The results showed that this system has $100 \%$ accuracy with a confidence value of $80.5 \%$.

This study aims to build an expert system to diagnose oral cancer and how to solve and prevent it. This study applies the CF algorithm to overcome uncertainty in the development of an expert system so that it can help and provide knowledge to the public in diagnosing oral cancer based on the symptoms felt or experienced. The expert system will be developed based on a website so that it can be used easily, anywhere and anytime.

\section{RESEARCH METHODS}

To carry out research, there are several stages carried out. In the expert system research, the diagnosis of oral cancer consists of the following stages:

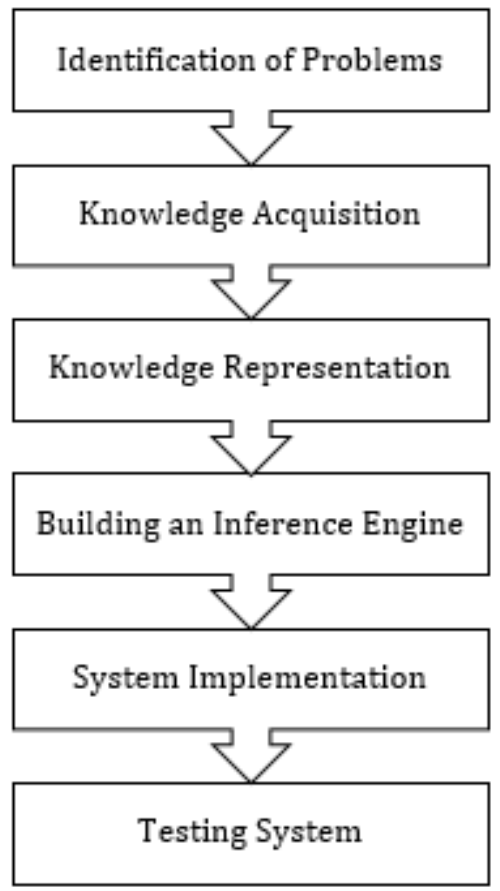

Figure 1. Research Stages

Identification of Problems 
In building an expert system in diagnosing oral cancer, it begins with problem identification. Problem identification has the aim of knowing the main problem and determining the need to provide solutions to these problems (Rahmanto, Alfian, \& Borman, 2021).

Oral cancer or oral cavity cancer is a head and neck cancer with the highest mortality rate compared to all types of malignancies. However, many people are not aware of this disease. Lack of knowledge from the community can cause the number of people with oral cancer to increase. For that we need a system that can diagnose and provide knowledge and provide solutions for oral cancer.

\section{Knowledge Aquisition}

To build an expert system requires a collection of knowledge obtained from experts. So, a knowledge acquisition process is needed. Knowledge acquisition is a process of exploring, organizing and organizing knowledge from knowledge sources that are used as knowledge bases in expert systems (Borman et al., 2020). Knowledge acquisition through the stages of extracting information from experts including problem solving in certain cases (Sucipto, Fernando, Borman, \& Mahmuda, 2019). This stage involves the process of obtaining knowledge from sources of knowledge obtained from experts, books, documents, or other sources of knowledge (Konstantinopoulou, Kovas, Hatzilygeroudis, \& Prentzas, 2019).

In this study, to obtain data or information about oral cancer such as symptoms, diseases, solutions and the value of trust for each symptom, observations and interviews were carried out. The data collected came from the results of consultations with Surgical Oncology Experts at the Regional Hospital Dr. Hi Abdul Moeloek, Lampung Province. From the results of observations and interviews with experts, it was found that there are five oral cancers that are often suffered by the community. In addition to symptom and disease data, data on the weight or level of confidence obtained from experts is also needed. The weight data is based on the guidelines from the terms table (interpretation). Table 1 below is a table of terms (interpretation) which is used as a reference in giving the weight of the level of confidence.

Table 1. Terms (Interception)

\begin{tabular}{clc}
\hline No. & Interpretation & Weight \\
\hline $\mathbf{1}$ & Definitely not & -1.0 \\
\hline $\mathbf{2}$ & Almost certainly not & -0.8
\end{tabular}

\begin{tabular}{clc}
\hline No. & \multicolumn{1}{c}{ Interpretation } & Weight \\
\hline $\mathbf{3}$ & Most likely not & -0.6 \\
\hline $\mathbf{4}$ & Probably not & -0.4 \\
\hline $\mathbf{5}$ & Don't know/not sure & $-0.2--0.2$ \\
\hline $\mathbf{6}$ & Possible & 0.4 \\
\hline $\mathbf{7}$ & Most likely & 0.6 \\
\hline $\mathbf{8}$ & Almost sure & 0.8 \\
\hline $\mathbf{9}$ & Certainly & 1.0 \\
\hline
\end{tabular}

The data on symptoms, diseases and the level of confidence (weight) from the experts are presented in the following Table 2 .

Table 2. Symptoms, Disease and Weight Data

\begin{tabular}{|c|c|c|c|}
\hline No. & Symptoms & Weight & Disease \\
\hline 1 & $\begin{array}{l}\text { Lip color doesn't } \\
\text { look pink }\end{array}$ & 0.6 & \multirow{6}{*}{ Lip Cancer } \\
\hline 2 & $\begin{array}{l}\text { Lips look dry and } \\
\text { easily irritated }\end{array}$ & 0.8 & \\
\hline 3 & $\begin{array}{l}\text { Pain in the area } \\
\text { around the lips }\end{array}$ & 0.6 & \\
\hline 4 & $\begin{array}{l}\text { Sores in the } \\
\text { mouth that are } \\
\text { difficult to heal }\end{array}$ & 0.8 & \\
\hline 5 & $\begin{array}{l}\text { Bleeding on the } \\
\text { lips }\end{array}$ & 0.6 & \\
\hline 6 & $\begin{array}{l}\text { Often experience } \\
\text { numbness in the } \\
\text { oral cavity }\end{array}$ & 0.6 & \\
\hline 7 & $\begin{array}{l}\text { Sores in the } \\
\text { mouth that are } \\
\text { difficult to heal }\end{array}$ & 0.8 & \multirow{5}{*}{ Tongue Cancer } \\
\hline 8 & $\begin{array}{l}\text { Often experience } \\
\text { numbness in the } \\
\text { oral cavity }\end{array}$ & 0.4 & \\
\hline 9 & $\begin{array}{l}\text { Pain in the area } \\
\text { around the } \\
\text { tongue }\end{array}$ & 0.8 & \\
\hline 10 & $\begin{array}{l}\text { There is a lump } \\
\text { on the tongue }\end{array}$ & 0.8 & \\
\hline 11 & $\begin{array}{l}\text { Red or white } \\
\text { patches on the } \\
\text { tongue }\end{array}$ & 0.6 & \\
\hline 12 & $\begin{array}{l}\text { Often experience } \\
\text { numbness in the } \\
\text { oral cavity }\end{array}$ & 1.0 & \multirow{5}{*}{ Gum Cancer } \\
\hline 13 & $\begin{array}{l}\text { Inflammation of } \\
\text { the gums }\end{array}$ & 0.8 & \\
\hline 14 & $\begin{array}{l}\text { Pain in the Gum } \\
\text { Area }\end{array}$ & 0.8 & \\
\hline 15 & $\begin{array}{l}\text { Difficulty chewing } \\
\text { and swallowing } \\
\text { food }\end{array}$ & 0.6 & \\
\hline 16 & It's hard to talk & 0.8 & \\
\hline
\end{tabular}




\begin{tabular}{|c|c|c|c|}
\hline No. & Symptoms & Weight & Disease \\
\hline 14 & $\begin{array}{l}\text { Sores in the } \\
\text { mouth that are } \\
\text { difficult to heal }\end{array}$ & 0.8 & \multirow{4}{*}{$\begin{array}{l}\text { Oral Base } \\
\text { Cancer }\end{array}$} \\
\hline 15 & $\begin{array}{l}\text { Often experience } \\
\text { numbness in the } \\
\text { oral cavity }\end{array}$ & 0.4 & \\
\hline 16 & $\begin{array}{l}\text { The presence of a } \\
\text { lump on the } \\
\text { mucous } \\
\text { membrane found } \\
\text { at the bottom of } \\
\text { the floor of the } \\
\text { mouth }\end{array}$ & 0.8 & \\
\hline 17 & $\begin{array}{l}\text { Thickening of the } \\
\text { tissue lining the } \\
\text { surface of the oral } \\
\text { cavity }\end{array}$ & 0.8 & \\
\hline 18 & $\begin{array}{l}\text { Presence of lumps } \\
\text { in the mouth }\end{array}$ & 0.8 & \multirow{6}{*}{ Jaw Cancer } \\
\hline 19 & $\begin{array}{l}\text { Often experience } \\
\text { numbness in the } \\
\text { oral cavity }\end{array}$ & 0.8 & \\
\hline 20 & $\begin{array}{l}\text { Abnormal tooth } \\
\text { growth }\end{array}$ & 0.6 & \\
\hline 21 & loose teeth & 0.8 & \\
\hline 22 & $\begin{array}{l}\text { Swelling of the } \\
\text { jaw }\end{array}$ & 0.8 & \\
\hline 23 & $\begin{array}{l}\text { Swollen lymph } \\
\text { nodes in the neck }\end{array}$ & 0.6 & \\
\hline
\end{tabular}

\section{Knowledge Representation}

After the knowledge acquisition stage, the next step is knowledge representation. This stage is the stage of regularly organizing the knowledge that has been obtained to encode expert knowledge into the appropriate media form. This stage has an important role in the development of an expert system, this is because a good solution will depend on a good representation as well $(\mathrm{Yu}, \mathrm{Wu}, \&$ Zhang, 2017). If the knowledge representation is not made properly then the impact will affect the next stage and the resulting system is not as desired (Muhammad, Garba, Oye, \& Wajiga, 2018). At this stage, symptoms, diseases and solutions are entered into the decision table and rules are made according to the knowledge that has been obtained from an expert which will later be used to make it easier to build an inference engine.

\section{Building an Inference Engine}

Certainty Factor (CF) is one of the techniques used to overcome uncertainty in decision making. The CF method is an approach that can be used to confirm a fact that is certain or uncertain (Fahrozi, Harahap, Syahputra, \& Pane, 2019). Certainty Factor (CF) can occur under various conditions. Among the conditions that occur is that there are several antecedents (in different rules) with the same consequence. To calculate $\mathrm{CF}$ can use the following equation:

$$
\mathrm{CF}[\mathrm{h}, \mathrm{e}]=\mathrm{MB}[\mathrm{h}, \mathrm{e}]-\mathrm{MD}[\mathrm{h}, \mathrm{e}]
$$

Where, $\mathrm{h}$ is a measure of confidence, and e is the percentage of confidence. For CF involving one premise, you can use the following equation:

$\mathrm{CF}[\mathrm{h}, \mathrm{e}]=\mathrm{CF}_{[\text {user] }} * \mathrm{CF}_{\text {[expert] }}$

As for CF with similar conclusions, you can use the following formula:

CFcombained $=\mathrm{CF} 1+\mathrm{CF} 2 *(1-\mathrm{CF} 1)$

Where $\mathrm{CF}_{1}$ and $\mathrm{CF}_{2}$ have the same hypothesis. $\mathrm{CF}_{1}$ is the value of the certainty factor of evidence 1 on the hypothesis, while $\mathrm{CF}_{2}$ is the value of the certainty factor of evidence 2 on the hypothesis. Then the result of the first $\mathrm{CF}_{\text {combined }}$ will be $\mathrm{C}_{\text {Fold. }}$.

\section{System Implementation}

Implementation is the stage where the system will be built through coding with a programming language (Herdiansah, Borman, \& Maylinda, 2021). The purpose of this stage is to create a user interface so that users can easily use the application. The application of an expert system for diagnosing oral cancer was developed based on a website with coding using the PHP programming language with Sublime Text text editor tools, while the database uses MySql.

\section{Testing System}

The next stage is to test the system. This stage aims to determine the performance of the application that was built (Borman et al., 2018). This stage also serves to ensure that the system can run well, free from errors and has optimal performance (Kurniawan, Iqbal, Friadi, Borman, \& Rinaldi, 2019). In this study, the test that will be carried out is with accuracy. Accuracy is obtained from the comparison of diagnostic results obtained by the expert system with answers from experts. For the accuracy value, use the following equation:

Accuracy $=\frac{\text { Number of correct predictions }}{\text { Total number of predictions }} \times 100 \%$

Where, the number of correct predictions is obtained from the number of diagnostic records by the system whose results are the same as diagnoses by an expert. While the total number of predictions is the total number of diagnosed cases. 


\section{RESULTS AND DISCUSSION}

The inference engine is the part that provides the mechanism for thinking functions and system reasoning patterns used by an expert. In building an expert system for diagnosing oral cancer using the Certainty Factor (CF) approach. CF solves the problem of uncertainty by justifying certain or uncertain facts. In the expert system developed, the user will make a diagnosis by presenting symptom questions then ending with a conclusion in the form of a diagnosis and solution. In the system developed, experts and users will be given a choice of the level of trust according to what is experienced and what has been determined. After selecting the confidence level, it will be processed with CF. The process of calculating CF starts from belief with rules based on facts or symptoms based on rules. The following is a case study in the application of $\mathrm{CF}$.

IF Lip color doesn't look pink

AND Lips look dry and easily irritated

AND Pain in the area around the lip

AND Bleeding on the lips

THEN Lip Cancer

In calculating $\mathrm{CF}$, it starts from determining the weight value for each symptom. For each weight and symptom obtained from the results of the acquisition of knowledge contained in table II. The following is the weight of the disease that has been determined by an expert.

$\mathrm{CF}_{\text {expert [symptoms 1] }}=0.6$
$\mathrm{CF}_{\text {expert [symptoms 2] }}=0.8$
$\mathrm{CF}_{\text {expert [symptoms 3] }}=0.6$
$\mathrm{CF}_{\text {expert [symptoms 4] }}=0.6$

Furthermore, the user who will diagnose determines the level of confidence in the symptoms that are adjusted to the conditions experienced. For this, the level of user confidence is as follows:

Symptom $1=0.8$ (Almost Certain)

Symptom $2=1.0$ (Certain)

Symptom $3=0.6$ (most likely)

Symptom $4=0.4$ (Maybe)

Then next, the level of trust of experts and users is adjusted according to predetermined rules Rule 1

IF Lip color doesn't look pink THEN Lip Cancer Rule 2

IF Lips look dry and easily irritated THEN Lip Cancer

Rule 3

IF Pain in the area around the lip THEN Lip Cancer

Rule 4

IF Bleeding on the lips THEN vibrio Lip Cancer
Rule 1 calculation process:

$$
\begin{aligned}
\mathrm{CF}_{\text {symptoms } 1} & =\mathrm{CF}_{\text {[user] }} * \mathrm{CF}_{\text {[expert] }} \\
& =0.8 * 0.6 \\
& =0.48
\end{aligned}
$$

Rule 2 calculation process:

$$
\begin{aligned}
\mathrm{CF}_{\text {symptoms 2 }} & =\mathrm{CF}_{\text {[user] }} * \mathrm{CF}_{\text {[expert] }} \\
& =1.0 * 0.8 \\
& =0.8
\end{aligned}
$$

Rule 3 calculation process:

$$
\begin{aligned}
\mathrm{CF}_{\text {symptoms } 3} & =\mathrm{CF}_{\text {[user] }} * \mathrm{CF}_{\text {[expert] }} \\
& =0.6 * 0.6 \\
& =0.36
\end{aligned}
$$

Rule 4 calculation process:

$$
\begin{aligned}
\mathrm{CF}_{\text {symptoms } 4} & =\mathrm{CF}_{\text {[user] }} * \mathrm{CF}_{\text {[expert] }} \\
& =0.4 * 0.6 \\
& =0.24
\end{aligned}
$$

In this case study, it consists of several symptoms, so getting the CF value uses the following calculations:

$$
\begin{aligned}
& \mathrm{CF}_{\text {combine } 1}\left(\mathrm{CF}_{\text {symptoms 1, }} \mathrm{CF}_{\text {symptoms 2 }}\right) \\
& =\mathrm{CF}_{\text {symptoms } 1}+\mathrm{CF}_{\text {symptoms } 2} *\left(1-\mathrm{CF}_{\text {symptoms } 1)}\right. \\
& =0.48+0.8 *(1-0.48)=0.896\left(\mathrm{CF}_{\text {old }} 1\right) \\
& \mathrm{CF}_{\text {combine } 2}\left(\mathrm{CF}_{\text {old } 1}, \mathrm{CF}_{\text {symptoms } 3)}\right. \\
& =\mathrm{CF}_{\text {old } 1}+\mathrm{CF}_{\text {symptoms } 3} *\left(1-\mathrm{CF}_{\text {old } 1}\right) \\
& =0.896+0.36 *(1-0.896)=0.933\left(\mathrm{CF}_{\text {old }} 2\right) \\
& \mathrm{CF}_{\text {combine } 3}\left(\mathrm{CF}_{\text {old 2 }}, \mathrm{CF}_{\text {symptoms } 3)}\right. \\
& =\mathrm{CF}_{\text {old } 2}+\mathrm{CF}_{\text {symptoms } 4} *\left(1-\mathrm{CF}_{\text {old } 2}\right) \\
& =0.933+0.24 *(1-0.933)=0.949\left(\mathrm{CF}_{\text {old } 3}\right)
\end{aligned}
$$

The final $\mathrm{CF}_{\text {fold }}$ is the result of disease $\mathrm{CF}$. Based on the results of these calculations, the last CFold result is 0.949 or $94.9 \%$. So based on the case study, the diagnosis is Lip Cancer.

Next is the implementation in the form of an expert system that can be used by users. Expert system development is done by making a program using a certain programming language to later become an application. The expert system application for diagnosing oral cancer was developed based on a website using the PHP programming language with Sublime Text text editor tools and MySql database. The application of an expert system for diagnosing oral cancer that has been developed has two users, namely: user and admin (as website manager). To make it easy to access, users who will diagnose oral cancer do not need to $\log$ in and can directly use the system. The main menu GUI display of the developed expert system application can be seen in Figure 2 below. 


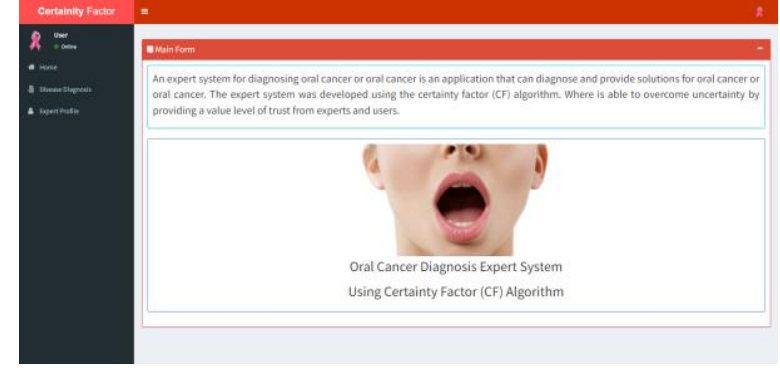

Figure 2. Main Menu Display of Expert System Applications

System users who will diagnose can choose the symptoms experienced and enter the user's level of trust according to what is felt. Then the system converts it into a value (weight) of the degree of confidence. Figure 3 below is a GUI display from the disease diagnosis page.

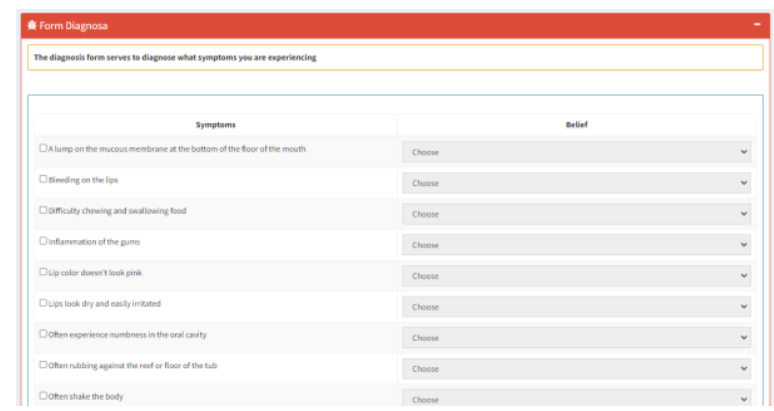

Figure 3. Disease Diagnosis Display

After the user selects the symptoms experienced, the system will display the results of the diagnosis. The display of the diagnosis results can be seen in Figure 4. From the display the system will display the disease and solutions based on each symptom and level of confidence in the questions that have been previously inputted by the user. The admin as the website manager can manage symptoms, diseases, expert rules and the weight of the level of trust as well as disease handling solutions.

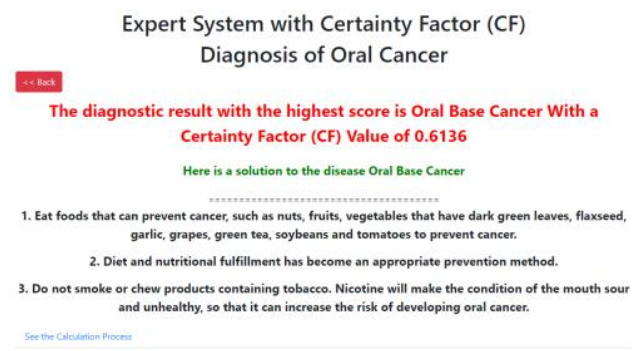

Figure 4. Display of Diagnostic Results

After the expert system is built, the next step is to conduct testing. This is done to ensure that the system can run as it should and the CF algorithm has a good performance in diagnosing. System testing is done by testing the accuracy. The accuracy test is carried out by matching the expert's analysis diagnosis with what is generated by the system. The test was carried out using a random sample of 30 cases to the user system and an expert. Then, the results will be compared and the number of correct diagnoses made by the expert system will be calculated. Calculation of accuracy using equation (3) which has been discussed previously. Figure 5 The following is a chart of the results of the accuracy tests carried out.

- Correct Diagnosis - Incorrect Diagnosis

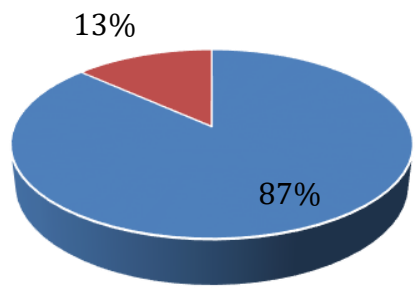

Figure 5. Chart of Accuracy Test Results

Of the 30 cases that have been tested, the expert system is able to answer validly as many as 27 cases or $87 \%$. While the error rate is $13 \%$. This is because there are several symptoms that are similar and shared by several diseases. This is what causes the emergence of almost the same value results, so there are different results from the diagnostic results by experts. The results of the accuracy are then converted and included in the accuracy level guidelines with the categories: Good, with a value of $76 \%-100 \%$; Enough, with a value of $56 \%-75 \%$; Less Good, with a value of $40 \%-55 \%$, while Less Good, has a value of less than $40 \%$ (Borman \& Purwanto, 2019). If it is included in that category, then the accuracy of the developed system is in the good category. This shows that the expert system for diagnosing oral cancer by applying the CF method can work well.

\section{CONCLUSIONS AND SUGGESTIONS}

\section{Conclusion}

In this paper, an expert system for diagnosing oral cancer is developed which can diagnose based on the symptoms selected by the user and then generate the disease and solutions. The expert system developed applies the Certainty Factor (CF) method. Where CF is able to overcome uncertainty by providing a value for the level of trust from experts and users. The results of the tests carried out show that the accuracy of the expert 
system developed is $87 \%$, so the system can function properly.

\section{Suggestion}

To improve further research, there are several things that can be developed, including: (1) comparing the algorithms of other expert systems, so as to get the algorithm with the best performance; (2) can add deep learning algorithms to get good accuracy results; (3) develop not only oral cancer but other diseases related to the mouth and oral cavity.

\section{REFERENCES}

Agustina, E., Pratomo, I., Wibawa, A. D., \& Rahayu, S. (2017). Expert System for Diagnosis Pests and Diseases of the Rice Plant Using Forward Chaining and Certainty Factor Method. 2017 International Seminar on Intelligent Technology and Its Application, 266-270. https://doi.org/10.1109/ISITIA.2017.81240 92

Astuti, I., Sutarno, H., \& Rasim. (2017). The Expert System of Children's Digestive Tract Diseases Diagnostic using Combination of Forward Chaining and Certainty Factor Methods. 2017 3rd International Conference on Science in Information Technology:(ICSITech), 608-612. https://doi.org/10.1109/ICSITech.2017.825 7185

Borman, R. I., Napianto, R., Nurlandari, P., \& Abidin, Z. (2020). Implementasi Certainty Factor Dalam Mengatasi Ketidakpastian Pada Sistem Pakar Diagnosa Penyakit Kuda Laut. JURTEKSI (Jurnal Teknologi Dan Sistem Informasi), $\operatorname{VII}(1), 1-8$.

Borman, R. I., \& Purwanto, Y. (2019). Impelementasi Multimedia Development Life Cycle pada Pengembangan Game Edukasi. JEPIN (Jurnal Edukasi Dan Penelitian Informatika)(Jurnal Edukasi Dan Penelitian Informatika), 5(2), 119-124.

Borman, R. I., Putra, Y. P., Fernando, Y., Kurniawan, D. E., Prasetyawan, P., \& Ahmad, I. (2018). Designing an Android-based Space Travel Application Trough Virtual Reality for Teaching Media. Proceedings of the 2018 International Conference on Applied Engineering, ICAE. https://doi.org/10.1109/INCAE.2018.85793 94

Desnelita, Y., Rukun, K., Syahril, Nasien, D., Gustientiedina, G. P. A. I., \& Vitriani. (2018). Intelligent Decision Support System Using Certainty Factor Method for Selection Student Career. Proceedings - 2018 2nd International
Conference on Electrical Engineering and Informatics: Toward the Most Efficient Way of Making and Dealing with Future Electrical Power System and Big Data Analysis, ICon EEI 2018, 18-23. https://doi.org/10.1109/IConEEI.2018.8784143

Fahmi, H., Nababan, A. A., Jannah, M., Khairani, M., Lubis, Y. F. A., \& Fahri, S. (2020). Analysis of Certainty Factor Methods to Determine Skills in Generation Y. MECnIT 2020 - International Conference on Mechanical, Electronics, Computer, and Industrial Technology, 222225.

https://doi.org/10.1109/MECnIT48290.202 0.9166646

Fahrozi, W., Harahap, C. B., Syahputra, A., \& Pane, R. (2019). Expert System of Diagnosing Koi's Fish Disease by Certainty Factor Method. 2018 6th International Conference on Cyber and IT Service Management, CITSM 2018, 8-12. https://doi.org/10.1109/CITSM.2018.86743 26

Hairani, Abdillah, M. N., \& Innuddin, M. (2019). An Expert System for Diagnosis of Rheumatic Disease Types Using Forward Chaining Inference and Certainty Factor Method. Proceedings of 2019 4th International Conference on Sustainable Information Engineering and Technology, SIET 2019, 104109.

https://doi.org/10.1109/SIET48054.2019.8 986035

Herdiansah, A., Borman, R. I., \& Maylinda, S. (2021). Sistem Informasi Monitoring dan Reporting Quality Control Proses Laminating Berbasis Web Framework Laravel. Jurnal TEKNO KOMPAK, 15(2), 13-24.

Irmawati, A. (2020). Penurunan Risiko Kanker Rongga Mulut Melalui Olahraga. Retrieved from Unair News website: http://news.unair.ac.id/2020/08/24/penur unan-risiko-kanker-rongga-mulut-melaluiolahraga/

Konstantinopoulou, G., Kovas, K., Hatzilygeroudis, I., \& Prentzas, J. (2019). An Approach using Certainty Factor Rules for Aphasia Diagnosis. 10th International Conference on Information, Intelligence, Systems and Applications, IISA 2019. https://doi.org/10.1109/IISA.2019.8900782

Kurniawan, D. E., Iqbal, M., Friadi, J., Borman, R. I., \& Rinaldi, R. (2019). Smart Monitoring Temperature and Humidity of the Room Server Using Smart Monitoring Temperature and Humidity of the Room Server Using Raspberry Pi and Whatsapp Notifications. Universitas Riau International Conference on 
Science and Environment 2020 (URICSE-2020), 1-8. https://doi.org/10.1088/17426596/1351/1/012006

Muhammad, L. J., Garba, E. J., Oye, N. D., \& Wajiga, G. M. (2018). On the Problems of Knowledge Acquisition and Representation of Expert System for Diagnosis of Coronary Artery Disease (CAD). International Journal of $U$ - and e-Service, Science and Technology, 11(3), 4958.

https://doi.org/10.14257/ijunesst.2018.11.3 .05

Napianto, R., Rahmanto, Y., Borman, R. I., Lestari, O., \& Nugroho, N. (2018). Dhempster-Shafer Implementation in Overcoming Uncertainty in the Inference Engine for Diagnosing Oral Cavity Cancer. CSRID (Computer Science Research and Its Development Journal), 13(1), 45-53.

Nikita, N., Sadawarti, H., \& Kaur, B. (2020). Classification of Renal Cancer using Principal Component Analysis (PCA) and K-Nearest Neighbour (KNN). International Journal of Engineering Research \& Technology (IJERT), 8(16), 156-159.

Pasaribu, S. A., Sihombing, P., \& Suherman, S.
(2020). Expert System for Diagnosing Dental and Mouth Diseases with a Website-Based Certainty Factor (CF) Method. MECnIT 2020 International Conference on Mechanical, Electronics, Computer, and Industrial Technology, 218-221. https://doi.org/10.1109/MECnIT48290.202 0.9166635

Rahmanto, Y., Alfian, J., \& Borman, R. I. (2021). Penerapan Algoritma Sequential Search pada Aplikasi Kamus Bahasa Ilmiah Tumbuhan. Jurnal Buana Informatika, 12(1), 21-30.

Sucipto, A., Fernando, Y., Borman, R. I., \& Mahmuda, N. (2019). Penerapan Metode Certainty Factor Pada Diagnosa Penyakit Saraf Tulang Belakang. Jurnal Ilmiah FIFO, 10(2), 18. https://doi.org/10.22441/fifo.2018.v10i2.00 2

Yu, S., Wu, L., \& Zhang, X. (2017). Research on Equipment Knowledge Representation Based on Visual Analytics. Proceedings - 2017 13th International Conference on Semantics, Knowledge and Grids, SKG 2017, 2018-Janua, 208-212.

https://doi.org/10.1109/SKG.2017.00043 